\section{Candelilla-shellac: An Alternative Formulation for Coating Apples}

\author{
Victorine Alleyne and Robert D. Hagenmaier ${ }^{1}$ \\ U.S. Department of Agriculture, Agricultural Research Service, Citrus and \\ Subtropical Products Laboratory, 600 Avenue S NW, Winter Haven, FL 33881 \\ Additional index words. candelilla, shellac, waxing, fruit-coating, quality, weight loss, \\ Malus $\times$ domestica
}

\begin{abstract}
An experimental candelilla-shellac formulation for coating apples (Malus $\times$ domestica Borkh.) was developed and compared with commercial shellac-based and carnauba-shellac-based coatings on 'Gala' and 'Delicious' apples by determining effects on quality attributes, respiration, and internal atmospheres. Fruit were stored at $5{ }^{\circ} \mathrm{C}$ for 7 days followed by storage at $21^{\circ} \mathrm{C}$ for 14 days. Gloss of 'Delicious' apples coated with candelilla-shellac formulations containing $7 \%$ to $34 \%$ shellac increased with increasing shellac concentrations. 'Gala' and 'Delicious' apples coated with a candelilla formulation containing $34 \%$ shellac maintained quality similar to those coated with commercial carnauba-shellac-based coatings, as indicated by gloss, firmness, internal $\mathrm{CO}_{2}, \mathrm{O}_{2}$ and ethanol levels, steady-state respiration rate, weight loss, and flavor. By comparison, shellac-coated fruit maintained the highest gloss throughout the experimental period. Shellac-coated apples were also firmer, contained more ethanol, and received higher flavor scores than did apples receiving other coating treatments. Gloss of all coated fruit decreased with time, although shellac-coated fruit lost less gloss over the 21-day storage period. Analysis of gloss, firmness, fruit respiration, ethanol, weight loss, and flavor demonstrate that the candelilla formulation containing $34 \%$ shellac is competitive with current commercial carnauba-based apple-coating products.
\end{abstract}

Apples usually are coated before market distribution, primarily to improve their appearance. Other benefits of wax coatings include shelf-life extension, reduction of weight loss and respiration rate, ripening retardation, and quality maintenance (Saftner et al., 1998). Commercial apple coatings are either shellac or carnauba-shellac based. These materials are associated with nonfood uses such as floor and car waxes. Alternative ingredients for shellac and carnauba-shellac must be found in the event that consumers become uncomfortable about their use on apples.

Candelilla wax, an extract from the plant Euphorbia antisyphilitica Zucc, is a generally recognized as safe (GRAS) substance that is permitted for use in certain foods with no limitations except good manufacturing practices (21 CFR, Code of Federal Regulations, 184.1976). Candelilla has extended the storage life of bananas (Musa sp.) (Siade and Pedraza, 1977), tomatoes (Lycopersicon esculentum), muskmelons (Cucumis melo L., Cantelupensis Group) (Siade et al., 1977), limes [Citrus aurantifolia (Christm.) Swingle] (ParedesLopez et al., 1974), and other citrus fruits (Lakshminarayana et al., 1974). Candelilla has

\footnotetext{
Received for publication 29 Mar. 1999. Accepted for publication 14 July 1999. Mention of a trademark or proprietary product is for identification only and does not imply a guarantee or warranty of the product by the U.S. Dept. of Agriculture. The U.S Dept. of Agriculture prohibits discrimination in all its programs and activities on the basis of race, color, national origin, gender, religion, age, disability, political beliefs, sexual orientation, and marital or family status.

${ }^{1}$ To whom reprint requests should be addressed. E-mail address: rhagenmaier@ithink.com.
}

plied, the apples were removed from cold storage and allowed to stand at room temperature $\left(\approx 25^{\circ} \mathrm{C}\right)$ for $24 \mathrm{~h}$. Coatings were applied manually, using $0.5 \mathrm{~mL} /$ fruit spread evenly over the surface using gloved hands. A pilotplant scale conveyor dryer (Central Florida Sales and Service, Auburndale) dried fruits at $50{ }^{\circ} \mathrm{C}$ for $5 \mathrm{~min}$. Fruits were then stored for 7 d at $5^{\circ} \mathrm{C}$, then $14 \mathrm{~d}$ at $21^{\circ} \mathrm{C}$ and $45 \%$ relative humidity (RH) in temperature-controlled rooms, to simulate marketing conditions. Coatings were evaluated in duplicate experiments, using 'Gala' apples in Expts. 1 and 2 and 'Delicious' apples in Expts. 3 and 4.

The experimental candelilla-shellac formulation was made by mixing a candelilla wax microemulsion with a shellac solution. The microemulsion was made in a pressure cell loaded with $300 \mathrm{~g}$ candelilla wax (No. 75; Strahl and Pitsch, W. Babylon, N.Y.), 30 g oleic acid (Emersol; Henkel Chemicals Group, Cincinnati), 15 g myristic acid (Emery 655; Henke Chemicals Group and Hystrene 9014; Witco Corp., Newark, N.J.), 41 g $30 \% \mathrm{NH}_{3}$, and $145 \mathrm{~g}$ water. This mixture was heated to $100^{\circ} \mathrm{C}, 900 \mathrm{~g}$ additional water was added, and the emulsion was mixed $5 \mathrm{~min}$, rapidly cooled in a water bath to $50{ }^{\circ} \mathrm{C}$, and adjusted to $20 \%$ total solids and $0.7 \%$ gelatin (Rousselot $75 \mathrm{~A}$; Bio-Industries, Waukesha, Wis.) with addition of water and gelatin solution. The shellac solution contained 20\% shellac (R52; Mantrose Haeuser, Attleboro, Mass.), 0.7\% gelatin, and $0.3 \% \mathrm{NH}_{3}$, and the $\mathrm{pH}$ was adjusted to 9.3 with additional $\mathrm{NH}_{4} \mathrm{OH}$. The shellac solution was added to the stirred candelilla wax emulsion to make formulations with shellac as $20 \%$ or $34 \%$ of the coating solids(CANDS20 and CANDS34, respectively). For example, CANDS20 consisted of $80 \%$ candelilla emulsion and $20 \%$ shellac solution. For the preliminary experiments, formulations with other percentages of shellac were also used. Experimental formulas were compared with two shellac coatings: AP40 (Shield-Brite Corp., Kirkland, Wash.) (SH1) and Vector 7 (Solutec Corp., Yakima, Wash.) (SH2); and two carnauba-shellac coatings: Apple Lustr 231 (Decco, Monrovia, Calif.) (CARS1) and Primafresh HS (Johnson's Wax, Racine, Wis.) (CARS2).

External quality (gloss), internal quality (firmness and sensory flavor), and physiological indicators (internal $\mathrm{CO}_{2}$ and $\mathrm{O}_{2}$, weight loss) were evaluated using 10 individual fruit replicates per treatment. Steady-state respiration rate was measured using two replicates of five fruit each. Composite samples from three fruits were used to evaluate ethanol content and sensory flavor.

Average gloss units (GU) at an angle of $60^{\circ}$ to a line normal with the fruit surface were measured using a micro-TRI-gloss reflectometer (BYK-Gardner, Silver Spring, Md.) equipped with a shield having a circular 19-mm-diameter aperture (Hagenmaier and Baker, 1994). Gloss of apples ranged from $\approx 3.0 \mathrm{GU}$ for noncoated fruit to 13.0 GU for shellac-coated fruit.

Apple firmness was assessed with a fruit pressure tester (model FT 327; McCormick, Facchini, Alfonsine, Italy), equipped with an 8-mm-diameter, flat cylinder plunger. Two 
measures of penetration force at $90^{\circ}$ angles were taken at opposite sides, in the equatorial plane of each fruit, after removing a $12-\mathrm{mm}$ diameter disc of peel.

Gas samples for internal gas measurements were obtained by submerging fruits under water, then inserting a syringe needle through the stylar end into the core cavity and withdrawing a 5-10-mL sample. Before sampling, the syringe was flushed with water to remove trapped air. The $\mathrm{CO}_{2}$ and $\mathrm{O}_{2}$ concentrations were analyzed using a gas chromatograph (GC) (HP5890A; Hewlett-Packard Co., Avondale, Pa.) equipped with a thermal conductivity detector. The column specifications consisted of a CTR-1 column (Alltech Associates, Deerfield, Ill.) consisting of an outer column $(1.8 \mathrm{~m} \times 6.4 \mathrm{~mm})$ packed with activated molecular sieve and an inner column $(1.8 \mathrm{~m} \times 3.2 \mathrm{~mm})$ packed with a porous polymer mixture. Operating conditions were: oven $40{ }^{\circ} \mathrm{C}$, detector $120{ }^{\circ} \mathrm{C}$, and a $250-\mu \mathrm{L}$ loop injector.

A continuous flow-through system was used to measure fruit steady-state respiration rate at $21^{\circ} \mathrm{C}$. Sealed glass jars $(3.8 \mathrm{~L})$ each containing $\approx 1 \mathrm{~kg}$ fruit were attached to a source of air. Humidity inside the jars was controlled at $\approx 43 \%$ by passing the flow-through air into a saturated solution of $\mathrm{K}_{2} \mathrm{CO}_{3} \cdot 2 \mathrm{H}_{2} \mathrm{O}$. Respiration rate was estimated from $\mathrm{CO}_{2}$ of exhaust air, air flow rate, and weight of the sample. A GC equipped with a $30 \mathrm{~m} \times 0.53 \mathrm{~mm}$ GSQ column I.D. (J\&W Scientific, Folsom, Calif.) and a thermal conductivity detector was used for $\mathrm{CO}_{2}$ analysis. Conditions for chromatography were identical to those indicated above.

Fruit ethanol concentration was determined from juice obtained by centrifuging homogenates of fruit and deionized water $(1: 1)$ at $7700 \mathrm{~g}$ 's for $15 \mathrm{~min}$. Juice samples $(100 \mathrm{~mL})$ were distilled prior to analysis. Distillation equipment consisted of a $500-\mathrm{mL}$ round bottom flask connected to a room temperature water-cooled Graham condenser (Ace Glass, Vineland, N.J.). The first 20-mL of distillate was spiked with $1 \mathrm{~mL} 1$-propanol, an internal standard, and $(5 \mu \mathrm{L})$ was injected on-column $(50 \mathrm{~m} \times 0.32 \mathrm{~mm}$, HP-FFAP; Hewlett-Packard Co.). Initial oven temperature was $55^{\circ} \mathrm{C}$ for $0.1 \mathrm{~min}$; then increased to $70{ }^{\circ} \mathrm{C}$ at $3{ }^{\circ} \mathrm{C} \mathrm{min}{ }^{-1}$ and held for $1.0 \mathrm{~min}$. Detector (flame ionization) and injector temperatures were $250{ }^{\circ} \mathrm{C}$.

Weight of 10 individual noncoated and coated fruit replicates was measured $1 \mathrm{~d}$ after coating and at 7-d intervals during storage. Weight loss for the 21-d storage period is presented as a percentage of initial weight.

After 21-d storage, hedonic scores were assigned by an untrained panel of 14 people, for which a score of 1 signified "dislike extremely" and a score of 9 signified "like extremely" was used. Each 5-g sample consisted of composite portions from three fruits. Samples were presented to evaluators in individual booths, under red illumination, in a closed room under positive pressure.

Data are means of duplicate experiments except where indicated. Analysis of variance was used to determine treatment effects and comparisons were made at $P \leq 0.05$ using
Tukey's honestly significant difference (HSD) (Statistix 2.0, Analytical Software, Tallahassee, Fla.).

\section{Results and Discussion}

Gloss of 'Delicious' apples increased with increasing concentrations of shellac added to candelilla wax formulations. Average gloss ranged from $8.7 \mathrm{GU}$ at $0 \%$ shellac to $10.1 \mathrm{GU}$ at $34 \%$ shellac. The commercial carnauba-shellac coating (CARS2) had mean gloss of 10.0 $\mathrm{GU}$, about the same as candelilla-shellac formulations containing $34 \%$ shellac.

The initial and final gloss of 'Gala' apples coated with CANDS34 was virtually the same as that of apples with the CARS2 coating (Fig. 1). Initial gloss of apples with CANDS20 was somewhat less than that of apples with the CARS2 coating. In general, coated apples had markedly higher initial gloss than noncoated fruit (Fig. 1). Gloss is a surface phenomenon associated with texture (Bennet, 1975), but the exact mechanism for gloss decay is unknown.

Coated 'Delicious' apples had higher initial gloss than noncoated fruit throughout the experimental period (Table 1). Apples coated with formulations containing only shellac had the highest gloss during the 21-d storage period. Of the two commercial carnauba-shellac coatings, one was superior to the candelilla-shellac coating both initially and after cold storage. Gloss of all fruit, coated and noncoated, decreased during storage; CARS2-coated fruit exhibited the greatest decrease while $\mathrm{SH} 2$ exhibited the least.

These results indicate that shellac-coated fruit had high initial gloss and maintained higher gloss than the wax-based formulations during cold storage and at room temperature. These findings differ from those reported for citrus by Hagenmaier and Baker (1994), where gloss of shellac coatings decreased more than that of wax coatings. This difference may be attributed to commodity differences in natural wax coat- ings, fruit surface topography, firmness and rigidity, and/or storage temperature regimen. Apples are very firm fruit with smooth surfaces, whereas citrus is a resilient fruit with many small surface indentations, and thus may be more prone to coating fractures due to handling. Gloss levels of fruit coated with candelillashellac generally were similar to those of fruit coated with carnauba-shellac throughout the experimental period. These results confirm that experimental candelilla-shellac coating can confer gloss characteristics to apples comparable to commercially used coating products.

Coated 'Gala' fruit contained higher $\mathrm{CO}_{2}$ and lower internal $\mathrm{O}_{2}$ levels than did noncoated fruit, but no difference between coatings was detected (Table 2). Coating treatments did not affect 'Gala' firmness values ranging from 31 to $33 \mathrm{~N}$. Steady-state respiration rate of 'Gala' apples was not affected by treatment, but rates ranged from $22.7 \mathrm{mg}^{-1} \cdot \mathrm{kg}^{-1} / \mathrm{h}$ in noncoated fruit to 16.0 in CARS2-coated fruit, suggesting a trend toward reduction in respiration rate because of coating. Ethanol content of 'Gala' fruit was not affected by treatment, and was generally low. Sensory flavor score was also unaffected by treatment. No specific trend was evident in terms of ethanol content and flavor.

'Delicious' apples coated with commercial shellac formulations were firmer than fruit treated with the other coatings or noncoated fruit (Table 3), but firmness of apples coated with candelilla-shellac and carnauba-shellac coatings was similar. In previous studies, commercial shellac coatings reduced softening and other evidence of ripening in 'Delicious' and 'Golden Delicious' apples (Drake and Nelson, 1990; Saftner et al., 1998).

All coatings increased internal $\mathrm{CO}_{2}$ and reduced internal $\mathrm{O}_{2}$ of 'Delicious' apples, with only small differences between the coatings (Table 3). These results agree fairly well with those of Drake and Nelson (1990), who found no differences among shellac, carnauba, and

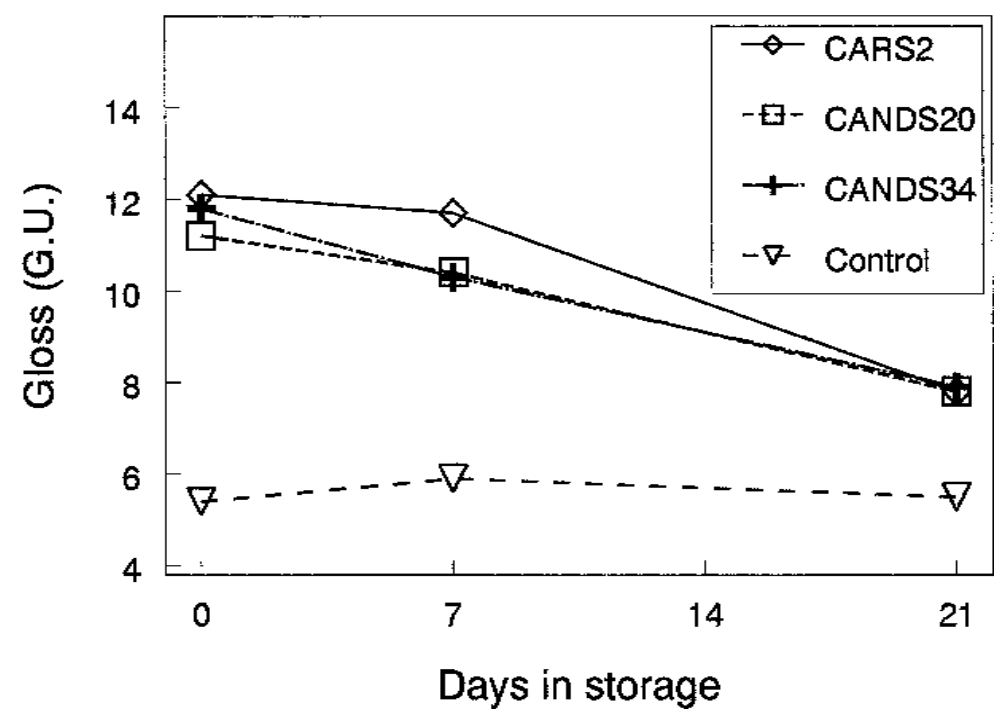

Fig. 1. Change in gloss of 'Gala' apples coated with experimental candelilla-shellac formulations (20\% and $34 \%$ shellac) and commercial carnauba-shellac formulation during storage at $5{ }^{\circ} \mathrm{C}$ for $7 \mathrm{~d}$ followed by $21{ }^{\circ} \mathrm{C}$ and $45 \%$ relative humidity for $14 \mathrm{~d}$. CANDS20 = candelilla-shellac $(20 \%$ shellac $)$; CANDS34 = candelilla-shellac ( $34 \%$ shellac); CARS2 = carnauba-shellac; Control = noncoated. Error bars are not shown because these are smaller than the symbols. Data represent one of two experiments with similar results. 
Table 1. Effect of storage on gloss of 'Delicious' apples coated with commercial shellac and carnauba coatings and an experimental candelilla-shellac formulation (34\% shellac), then stored at $5{ }^{\circ} \mathrm{C}$ for $7 \mathrm{~d}$ followed by $21^{\circ} \mathrm{C}$ and $45 \%$ relative humidity for $14 \mathrm{~d}$. SH1 and $\mathrm{SH} 2=$ commercial shellac coatings; CARS1 and CARS2 = commercial carnauba-shellac coatings; CANDS34 = experimental candelilla-shellac formulation ( $34 \%$ shellac).

\begin{tabular}{lccc}
\hline \hline & \multicolumn{3}{c}{ Gloss at $60^{\circ}(\mathrm{GU})$} \\
\cline { 2 - 4 } Coating & Initial $($ day 1$)$ & Intermediate $(\text { day } 8)^{\mathrm{z}}$ & Final $($ day 21$)$ \\
\hline SH1 & $13.0 \mathrm{a}^{\mathrm{y}}$ & $11.2 \mathrm{ab}$ & $10.6 \mathrm{a}$ \\
SH2 & $12.4 \mathrm{~b}$ & $11.3 \mathrm{a}$ & $11.2 \mathrm{a}$ \\
CARS1 & $10.5 \mathrm{c}$ & $9.7 \mathrm{~cd}$ & $7.6 \mathrm{c}$ \\
CARS2 & $11.9 \mathrm{~b}$ & $10.4 \mathrm{bc}$ & $8.2 \mathrm{~b}$ \\
CANDS34 & $10.4 \mathrm{c}$ & $9.0 \mathrm{~d}$ & $8.1 \mathrm{~b}$ \\
Noncoated & $5.5 \mathrm{~d}$ & $6.0 \mathrm{e}$ & $3.0 \mathrm{c}$ \\
\hline
\end{tabular}

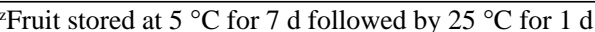

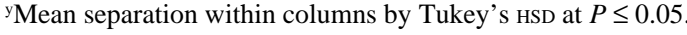

Table 2. Effect of fruit coatings on internal $\mathrm{CO}_{2}$ and $\mathrm{O}_{2}$ of 'Gala' apples coated with carnauba-shellac and candelilla-shellac formulations and stored for $7 \mathrm{~d}$ at $5^{\circ} \mathrm{C}$ followed by $14 \mathrm{~d}$ at $21^{\circ} \mathrm{C}$ and $45 \%$ relative humidity. CARS $2=$ commercial carnauba-shellac coating; CANDS20 and CANDS34 = experimental candelilla-shellac formulations (20\% and $34 \%$ shellac).

\begin{tabular}{lcc}
\hline Treatment & Internal $\mathrm{CO}_{2}(\%)$ & Internal $\mathrm{O}_{2}(\%)$ \\
\hline CARS2 & $6.8 \mathrm{a}^{2}$ & $10.8 \mathrm{~b}$ \\
CANDS20 & $6.7 \mathrm{a}$ & $11.5 \mathrm{~b}$ \\
CANDS34 & $7.6 \mathrm{a}$ & $10.3 \mathrm{~b}$ \\
Noncoated & $2.9 \mathrm{~b}$ & $17.7 \mathrm{a}$ \\
\hline
\end{tabular}

${ }^{\mathrm{z}}$ Mean separation within columns by Tukey's HSD at $P \leq 0.05$

Table 3. Effects of fruit coatings on quality characteristics of 'Delicious' apples coated with wax- and shellac-based formulations and stored for $7 \mathrm{~d}$ at $5{ }^{\circ} \mathrm{C}$ followed by $21^{\circ} \mathrm{C}$ and $45 \%$ relative humidity. SH1 and $\mathrm{SH} 2=$ commercial shellac coatings; CARS 1 and CARS $2=$ commercial carnauba-shellac coatings; CANDS34 = experimental candelilla-shellac formulation $(34 \%$ shellac $)$; UNC $=$ uncoated.

\begin{tabular}{|c|c|c|c|c|c|c|c|}
\hline \multirow[b]{2}{*}{ Treatment } & \multirow[b]{2}{*}{$\begin{array}{l}\text { Firmness } \\
(\mathrm{N})\end{array}$} & \multicolumn{2}{|c|}{ Internal gas content } & \multirow[b]{2}{*}{$\begin{array}{l}\text { Respiration rate of } \mathrm{CO}_{2}^{\mathrm{z}} \\
\left(\mathrm{mg} \cdot \mathrm{kg}^{-1} \cdot \mathrm{h}^{-1}\right)\end{array}$} & \multirow[b]{2}{*}{$\begin{array}{l}\text { Ethanol } \\
\left(\mu \mathrm{L} \cdot \mathrm{L}^{-1}\right)\end{array}$} & \multirow[b]{2}{*}{$\begin{array}{l}\text { Flavor } \\
\text { score }^{\mathrm{y}}\end{array}$} & \multirow[b]{2}{*}{$\begin{array}{l}\text { Wt loss } \\
(\%)\end{array}$} \\
\hline & & $\begin{array}{l}\mathrm{CO}_{2} \\
(\%)\end{array}$ & $\begin{array}{c}\mathrm{O}_{2} \\
(\%)\end{array}$ & & & & \\
\hline$\overline{\text { SH1 }}$ & $32 a^{x}$ & $9.9 \mathrm{ab}$ & $9.0 \mathrm{c}$ & $9.9 \mathrm{c}$ & $30.1 \mathrm{ab}$ & $7.2 \mathrm{a}$ & $1.7 \mathrm{~b}$ \\
\hline $\mathrm{SH} 2$ & $31 \mathrm{ab}$ & $10.1 \mathrm{a}$ & $8.9 \mathrm{c}$ & $10.8 \mathrm{bc}$ & $32.4 \mathrm{a}$ & $7.1 \mathrm{a}$ & $1.8 \mathrm{~b}$ \\
\hline CARS1 & $27 \mathrm{bc}$ & $8.4 \mathrm{bc}$ & $10.9 \mathrm{bc}$ & $14.3 \mathrm{~b}$ & $2.7 \mathrm{c}$ & $6.3 \mathrm{ab}$ & $1.6 \mathrm{~b}$ \\
\hline CARS2 & $26 \mathrm{~cd}$ & $8.0 \mathrm{c}$ & $11.3 \mathrm{bc}$ & $13.9 \mathrm{bc}$ & $2.0 \mathrm{c}$ & $6.7 \mathrm{ab}$ & $1.8 \mathrm{~b}$ \\
\hline CANDS34 & $28 \mathrm{bc}$ & $8.0 \mathrm{c}$ & $11.5 \mathrm{ab}$ & $12.4 \mathrm{bc}$ & $5.1 \mathrm{bc}$ & $6.9 \mathrm{a}$ & $1.5 \mathrm{~b}$ \\
\hline UNC & $23 \mathrm{~d}$ & $3.5 \mathrm{~d}$ & $17.6 \mathrm{a}$ & $18.8 \mathrm{a}$ & $3.5 \mathrm{bc}$ & $5.8 \mathrm{~b}$ & $2.4 \mathrm{a}$ \\
\hline
\end{tabular}

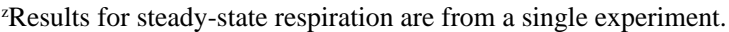

yean score on a scale of 1-9 on which 1 = "dislike extremely" and $9=$ "like extremely."

${ }^{x}$ Mean separation within columns by Tukey's HSD at $P \leq 0.05$.

resin treatments on 'Delicious' and 'Golden Delicious' apples with respect to internal $\mathrm{CO}_{2}$. Hagenmaier and Baker (1994), on the other hand, found 2-fold differences in internal $\mathrm{CO}_{2}$ and several-fold differences in internal $\mathrm{O}_{2}$ between shellac- and wax-coated citrus fruit. Metabolic differences between citrus and apples may explain the virtual absence of treatment effects in apples.

All coatings reduced steady-state respiration rate of 'Delicious' apples, and SH1-coated apples had a significantly lower respiration rate than those coated with CARS20 (Table 3). The trend towards higher $\mathrm{CO}_{2}$ and lower $\mathrm{O}_{2}$ that characterized shellac-coated apples correlates with observed lower respiration rates, and emphasizes the influence of the coating-mediated modified internal atmosphere on fruit respiration rate.

Shellac-coated 'Delicious' apples contained much more ethanol than did the other treatments (Table 3). Fruit coatings form a diffusion barrier that restricts flux of $\mathrm{CO}_{2}$ and $\mathrm{O}_{2}$, thereby modifying metabolism, depending on permeability of coating. Shellac is less permeable to oxygen than candelilla and carnauba waxes
(Donhowe and Fennema, 1993), and low oxygen can enhance fermentation (Mattheis et al., 1991; Smith et al., 1987). Even so, the rather small differences in internal gases would not seem sufficient to account for the large differences in ethanol. Shellac coatings also may be less permeable to ethanol than the wax coatings, leading to entrapment and accumulation of higher concentrations of this compound in the shellac-coated fruit.

Despite their higher ethanol content, the shellac-coated 'Delicious' apples received higher flavor scores than noncoated fruit (Table 3), probably in part because they were firmer and therefore less ripe (Saftner et al., 1998). The trend toward better flavor in coated than in noncoated fruit may have resulted from changes in flavor volatiles (Smith et al., 1987). Volatiles in shellac-coated fruit may have been altered as a result of conversion of ethanol to ethyl esters (Mattheis et al., 1991), as well as other metabolic processes and/or entrapment by the coating.

All coatings markedly reduced weight loss in 'Delicious' fruit (Table 3), but differences among coatings were not significant.
In summary, an experimental candelilla formulation with $34 \%$ shellac conferred gloss characteristics comparable to those of commercial carnauba-shellac coatings on 'Delicious' and 'Gala' apples. Firmness, ethanol content, and flavor of apples coated with candelillashellac were similar to those of carnauba-shellac-coated fruit. In general, quality of the former was similar to that of apples coated with commercial carnauba products.

Shellac-coated 'Delicious' apples had higher gloss, firmness, and ethanol content than waxcoated fruit. Shellac and wax-shellac coatings on 'Delicious' and 'Gala' apples reduced internal $\mathrm{O}_{2}$, increased internal $\mathrm{CO}_{2}$, and reduced steady-state respiration rate and weight loss of 'Delicious' apples. Flavor tended to be better in coated than noncoated apples. 'Delicious' apples were more responsive to coating treatments than were 'Gala' apples.

\section{Literature Cited}

Baldwin, E.A., M. Nisperos-Carriedo, P.E. Shaw, and J.K. Burns. 1995. Effect of coatings and prolonged storage conditions on fresh orange flavor volatiles, degrees Brix, and ascorbic acid levels. J. Agr. Food Chem. 43:1321-1331.

Bennet, H. 1975. Industrial waxes, vol. 1. Chem. Publ. Co., New York.

Code of Federal Regulations, Title 21. 1995.

Donhowe, I.G. and O. Fennema. 1993. Water vapor and oxygen permeability of wax films. J. Amer. Oil Chem. 70:867-873.

Drake, S.R. and J.W. Nelson. 1990. Storage quality of waxed and non-waxed 'Delicious' and 'Golden Delicious' apples. J. Food Qual. 13:331-341.

Hagenmaier, R.D. and R.A. Baker. 1994. Internal gases, ethanol content and gloss of citrus fruit coated with polyethylene wax, carnauba wax, shellac or resin at different application levels. Proc. Fla. State Hort. Soc. 107:261-265.

Hernandez, E. 1994. Edible coatings from lipids and resins, p. 279-303.In:J.M. Krochta,E.A. Baldwin, and M. Nisperos-Carriedo (eds.). Edible coatings and films to improve food quality. Technomic, Lancaster, Pa.

Lakshminarayana, S., L.L. Sarmiento, R.J.I. Ortiz, and G. Siade. 1974. Extension of storage life of citrus fruits by application of candelilla wax emulsion and comparison of its efficiency with tag and flavorseal. Proc. Fla. State Hort. Soc. 87:325-330.

Mattheis, J.P., D.A. Buchanan, and J.K. Fellman. 1991. Changes in apple fruit volatiles after storage in atmospheres inducing anaerobic metabolism. J. Agr. Food Chem. 39:1602-1605.

Parades-Lopez, O., E. Camargo-Rubio, and Y. Gallardo-Navarro. 1974. Use of coatings of candelilla wax for the preservation of limes. J. Sci. Food Agr. 25:1207-1210.

Saftner, R.A., W.S. Conway, and C.E. Sams. 1998. Effects of postharvest calcium and fruit coating treatments on postharvest life, quality maintenance, and fruit-surface injury in 'Golden Delicious' apples. J. Amer. Soc. Hort. Sci. 123:294-298

Siade, G. and E. Pedraza. 1977. Extension of storage life of banana (Giant Cavendish) using natural candelilla wax. Acta Hort. 62:327-334.

Siade, G.C., C. Pelayo, and D. Castillo. 1977. Extension of storage life of tomatoes cv. Tropic and cantaloupe cvs. pMR-45 and Top Mark-S.r. using natural wax candelilla. Acta Hort. 62:335344.

Smith S., J. Geeson, and J. Stow. 1987. Production of modified atmospheres in deciduous fruits by the use of films and coatings. HortScience 22:772776 